AKRUAL 3 (1) (2011): 15-37 e-ISSN: 2502-6380

AKRUAL

Jurnal Akuntansi

http://fe.unesa.ac.id/ojs/index.php/akrl

\title{
PENERAPAN ANALISIS SWOT SEBAGAI DASAR PENENTUAN STRATEGI PENINGKATAN KINERJA PT. BANK X DI SURABAYA
}

\author{
Lintang Venusita \\ Fakultas Ekonomi Universitas Negeri Surabaya \\ Pramita Kartika Sari \\ Fakultas Ekonomi Universitas Bhayangkara \\ Email: lvenusita@yahoo.com
}

Artikel diterima: 20 Agustus 2011

Terakhir direvisi: 10 Oktober 2011

\begin{abstract}
Performance is the result or degree of the person's overall success for a certain period in the task compared with a range of possibilities, such as working standards, targets or goals or criteria are predetermined and mutually agreed. Researchers have identified a phenomenon that occurs in the PT. Bank X can see how the application of a SWOT analysis as a basis for determining the performance improvement strategy. The purpose of this study was to determine the strategy to improve the performance of PT. Bank X. Of acquisition score internal-external quadrant is known that the position of PT. Bank X is located at coordinates (-0.44; -0.26) are in a position or is in quadrant IV Defensive strategy (WT) is an unfortunate situation for PT. Bank $X$ because the direction of defensive strategy indicates that the PT. Bank X has the environmental threats of the temporary position is relatively weak and should strive to minimize weaknesses and avoid threats that occur. Some suggestions are presented, among others, development and training to improve skills and quality, product innovation and improve the quality of the service to customers, adding to the facilities and infrastructure to support the activities of banks, the selection of candidates before the merger partners.
\end{abstract}

Keywords: Performance, Strategy, SWOT Analysis, Strategic Defense

\section{PENDAHULUAN}

\section{Latar Belakang}

Kinerja adalah hasil atau tingkat keberhasilan seseorang secara keseluruhan selama periode tertentu di dalam melaksanakan tugas dibandingkan dengan berbagai kemungkinan, seperti standar hasil kerja, target atau sasaran atau kriteria yang telah ditentukan terlebih dahulu dan telah disepakati bersama. Kinerja bisa diketahui hanya jika individu atau kelompok individu tersebut mempunyai kriteria keberhasilan yang telah ditetapkan. Kriteria keberhasilan ini berupa tujuan-tujuan atau target-target 
tertentu yang hendak dicapai. Tanpa ada tujuan atau target, kinerja seseorang atau organisasi tidak mungkin dapat diketahui karena tidak ada tolok ukurnya. Selain itu kinerja adalah hasil kerja yang dapat dicapai oleh seseorang atau kelompok orang dalam suatu perusahaan sesuai dengan wewenang dan tanggung jawab masingmasing dalam upaya pencapaian tujuan perusahaan secara legal tidak melanggar hukum dan tidak bertentangan dengan moral atau etika. Melihat definisi diatas Burhanuddin Abdullah (2005:16) mengemukakan bahwa kinerja pada dasarnya ditentukan oleh tiga hal yaitu kemampuan, keinginan, dan lingkungan.

Hasil penelitian menunjukkan adanya hubungan antara organisasi dan lingkungan yang menjelaskan bagaimana lingkungan dapat mempengaruhi kinerja suatu organisasi. Organisasi atau perusahaan tidak berdiri sendiri tetapi berinteraksi dengan bagian-bagian dari lingkungannya dan lingkungan itu sendiri selalu berubah setiap saat. Lingkungan sebagaimana umum diartikan meliputi kondisi, situasi keadaan, peristiwa, dan pengaruh-pengaruh yang mengelilingi dan mempengaruhi perkembangan organisasi. Jadi setiap organisasi senantiasa berinteraksi dengan lingkungan. Bahkan kadang-kadang organisasi dapat mempengaruhi lingkungan tetapi pada umumnya organisasi lebih banyak dipengaruhi oleh lingkungan. Lingkungan yang seringkali mempengaruhi kinerja organisasi yaitu lingkungan internal dan lingkungan eksternal.

Di dalam perkembangan dunia usaha khususnya pada organisasi perbankan kinerja atau performance usaha sangat diperlukan untuk melihat tingkat kesehatan suatu bank. Kesehatan atau kondisi keuangan atau non keuangan bank tertentu merupakan kepentingan semua pihak terkait, baik pemilik, pengelola (manajemen) bank, masyarakat pengguna jasa bank, Bank Indonesia selaku otoritas pengawasan bank, serta pihak lainnya. Kondisi bank seperti itu dapat digunakan oleh pihak-pihak tersebut untuk mengevaluasi kinerja bank dalam menerapkan prinsip kehati-hatian, kepatuhan terhadap ketentuan yang berlaku dan manajemen risiko. Bank berperan sangat penting yaitu sebagai penghimpun dan penyalur dana yang asalnya dari masyarakat berusaha untuk memberikan suatu kinerja yang baik. Aktivitas lainnya yang dapat memberikan pendapatan ke bank adalah jasa-jasa bank dalam lalu lintas pembayaran dan peredaran uang. Saat ini, jasa-jasa bank yang diberikan ke nasabah selalu disesuaikan dengan kebutuhan masyarakat. Berbagai jenis produk yang ditawarkan ke masyarakat ditujukan untuk memenuhi seluruh kebutuhan dan keinginan masyarakat dalam melakukan transaksi keuangan. Pilihan nasabah yang utama atas bank tertentu adalah kepercayaan, jasa-jasa keuangan yang dapat memenuhi sebagian besar kebutuhan yang diinginkan, pelayanan yang sesuai dengan segmentasi nasabah, dan perkiraan tingkat pendapatan. Pilihan lainnya tergantung pada karakter dan harapan nasabah ketika mereka memutuskan untuk menjadi nasabah bank tertentu. Umumnya kepercayaan timbul karena penilaian nasabah terhadap tingkat risiko yang akan dihadapi apabila mereka menyimpan dananya di bank tertentu. Semakin rendah penilaian tingkat risiko terhadap bank tertentu akan semakin meningkatkan loyalitas. Sebagian besar masyarakat berharap dengan adanya bank mereka dapat menitipkan uangnya dengan harapan uang mereka 
akan bertambah dari bulan ke bulan, selain itu masyarakat yang berprofesi mendirikan suatu usaha juga berharap pada suatu bank dapat memberikan fasilitas kemudahan kredit sebagai modal usaha. Untuk itu suatu bank harus memiliki kinerja yang baik sehingga tingkat kepercayaan masyarakat terhadap bank tersebut dapat meningkat. Bank harus dikelola dengan baik, pengelolaan pada masing-masing bank memerlukan strategi yang tepat terutama dalam kondisi persaingan perbankan yang sangat ketat.

Pada PT. Bank X ini memiliki tujuan yang sama dengan organisasi perbankan lainnya yaitu menjadi suatu bank yang memiliki kinerja yang baik. Dukungan dari lingkungan internal dan lingkungan eksternal sangat dibutuhkan untuk terwujudnya suatu kinerja. Beberapa waktu yang lalu PT. Bank X ini tergolong bank yang memiliki kinerja yang baik sehingga semua yang ditargetkan dapat tercapai, karena banyaknya persaingan yang semakin global dalam dunia perbankan maka PT. Bank X ini dari tahun ke tahun menunjukkan grafik kinerja yang menurun. Perlu diketahui dunia perbankan di Indonesia pada saat ini mengalami persaingan yang sangat ketat. Dengan jumlah bank yang cukup banyak, perbankan harus melakukan banyak inovasi dalam rangka menarik minat masyarakat untuk menyimpan dananya di bank. Umumnya berbagai jenis produk yang ditawarkan ke masyarakat ditujukan untuk memenuhi seluruh kebutuhan dan keinginan masyarakat dalam melakukan transaksi keuangan. Keadaaan yang mempengaruhi PT. Bank $X$ ini seperti sumber daya manusia yang dimiliki banyak sekali, tetapi jumlah sumber daya manusianya tidak di dukung dengan kualitas yang dimiliki. Pada PT. Bank X ini pelatihan kepada para karyawannya jarang dilakukan sehingga kualitas sumber daya manusianya kurang menunjukkan adanya peningkatan. Dapat dilihat dengan banyaknya kesalahan yang dilakukan dalam setiap penyelesaian pekerjaan. Nama atau branded dari PT. Bank X masih kurang dikenal banyak masyarakat meski telah berdiri lima puluh tahun yang lalu, karena banyaknya bank lain yang lebih memiliki nama atau branded maka masyarakat lebih mempercayakan uang mereka ke bank lain tersebut. Di Bank ini jumlah nasabah yang ada tergolong kecil. Hal ini dapat dikarenakan karena beberapa faktor diantaranya adalah produk atau jasa yang ditawarkan masih sedikit dan proses pengenalan ke masyarakat juga kurang. Faktor lainnya juga bisa diakibatkan karena fasilitas dalam bank kurang memadai, misalnya : tidak adanya ATM sehingga dalam pengambilan uang nasabah harus datang ke bank yang bersangkutan dan proses pengambilan uangnya dengan menggunakan slip pengambilan tunai. Suatu bank untuk mencapai target labanya tiap bulan bergantung pada bunga yang akan diterima. Untuk itu dalam usahanya bank juga harus mencari sebanyak - banyaknya debitur. Dengan bertambahnya debitur maka bunga yang masuk akan bertambah sehingga laba yang diperoleh akan meningkat. Selama ini PT. Bank X dalam usahanya mencari debitur masih kurang, disini dapat dilihat dengan banyaknya debitur lama dan sedikitnya debitur baru. Hal ini perlu dukungan oleh banyak pihak terutama para Account officer. Selain itu laba yang dihasilkan dari tahun ke tahun masih belum memenuhi target yang diharapkan meski terjadi adanya peningkatan yang relatif kecil dari tahun ke tahun. Hal yang seringkali terjadi diakibatkan karena fasilitas kredit 
tidak digunakan sebagaimana mestinya sehingga masih banyak terdapat fasilitas terbuka.

Dari uraian diatas maka yang lebih tepat untuk meningkatkan kinerja organisasi adalah meningkatkan peranan lingkungan internal dengan lingkungan eksternal. Dalam lingkungan internal diharapkan suatu bank dapat menggali dan mengidentifikasi suatu kekuatan (Strength) dan kelemahan (Weakness) sedangkan lingkungan eksternal lebih memfokuskan pada identifikasi suatu peluang (Oportunity) dan ancaman (Threat). Dalam melakukan kedua analisa tersebut maka suatu perusahaan dapat menggunakan analisa SWOT. Diharapkan dengan penerapan analisa SWOT maka dapat menjadi tolok ukur bank di dalam proses meningkatkan kinerjanya sehingga di masa mendatang pada PT. Bank X ini dapat menjadi suatu bank yang sehat, berkinerja baik dan menjadi kepercayaan banyak masyarakat.

\section{Rumusan Masalah}

Rumusan masalah berdasarkan identifikasi masalah diatas dalam penelitian ini adalah: "Bagaimanakah strategi untuk meningkatkan kinerja PT. Bank X"

\section{Tujuan Penelitian}

Tujuan yang ingin dicapai dalam penelitian ini yaitu untuk menentukan strategi peningkatan kinerja PT. Bank X.

\section{KAJIAN PUSTAKA}

Kinerja adalah hasil atau tingkat keberhasilan seseorang secara keseluruhan selama periode tertentu di dalam melaksanakan tugas dibandingkan dengan berbagai kemungkinan seperti standar hasil kerja, target atau sasaran atau kriteria yang telah ditentukan terlebih dahulu dan telah disepakati bersama (Abdullah,2005). Menurut Jurnal Riset Ekonomi dan Manajemen (2002:8-9) kinerja merupakan terjemahan dari performance. Performance berdasarkan kamus bisnis dan manajemen adalah hasil nyata yang dicapai, kadang-kadang dipergunakan untuk menunjukkan dicapainya hasil yang positif. Oleh karena itu setiap unit usaha akan selalu mengukur dan memiliki kinerja usahanya agar diketahui tingkat hasil nyata yang dapat dicapai dalam unit tersebut dalam kurun waktu tertentu. Faktor - faktor yang mempengaruhi kinerja adalah faktor kemampuan (ability) dan faktor motivasi (motivation). Hal ini sesuai dengan pendapat Keith Davis dalam Mangkunegara (2000:67) yang merumuskan bahwa :

$\begin{array}{ll}\text { Human Performance } & =\text { Ability } x \text { Motivation } \\ \text { Motivation } & =\text { Attitude } x \text { Situation } \\ \text { Ability } & =\text { Knowledge } x \text { Skill }\end{array}$

Menurut (Umar, 2001) Strategi merupakan tindakan yang bersifat incremental atau senantiasa meningkat, dan terus menerus, serta dilakukan berdasarkan sudut pandang tentang apa yang diharapkan oleh para pelanggan di masa depan. Dengan demikian strategi hampir selalu dimulai dari apa yang terjadi dan bukan dimulai dari 
apa yang terjadi dan bukan dimulai dari apa yang terjadi. Terjadinya kecepatan inovasi pasar yang baru dan perubahan pola konsumen memerlukan kompetensi inti. Perusahaan perlu mencari kompetensi inti di dalam bisnis yang dilakukan.

Menurut Panduan Audit Bank IAI (1994:1) Bank adalah badan usaha yang menghimpun dana dari masyarakat dalam bentuk simpanan dan menyalurkan kepada masyarakat dalam rangka meningkatkan taraf hidup rakyat banyak. Peranan perbankan sangat penting dalam suatu perekonomian karena bank dalam kegiatan operasinya mempertemukan pemilik dana dengan pengguna dana. Dasar utama kegiatan bank adalah kepercayaan masyarakat, sehingga setiap bank perlu terus menjaga dan memelihara kepercayaan masyarakat tersebut. Perbankan dalam menjalankan usahanya berazaskan demokrasi ekonomi dengan menggunakan prinsip kehati-hatian dan bertujuan untuk menunjang pelaksanaan pembangunan nasional dalam rangka meningkatkan pemerataan, pertumbuhan ekonomi dan stabilitas nasional ke arah peningkatan kesejahteraan rakyat banyak. Menurut Pasal 3 UU No. 10/1998 dalam Ade Arthesa,et al ( 2006:13 ) tujuan perbankan Indonesia adalah menunjang pelaksanaan pembangunan nasional dalam rangka meningkatkan pemerataan, pertumbuhan ekonomi, dan stabilitas nasional ke arah peningkatan kesejahteraan rakyat banyak. Sesuai dengan Undang-undang No 7 tahun 1992 tentang perbankan menurut jenisnya bank dapat dibedakan menjadi Bank Umum dan Bank perkreditan rakyat. Fungsi utama bank adalah menghimpun dana dari masyarakat dan menyalurkannya kembali kepada masyarakat untuk berbagai tujuan atau sebagai financial intermediary. Menghimpun yang artinya secara langsung berupa simpanan dana masyarakat baik berupa tabungan, giro maupun deposito, secara tidak langsung dari masyarakat baik berupa kertas berharga, penyertaan, pinjaman atau kredit dari lembaga lain. Penyaluran dana yang artinya untuk tujuan modal kerja, investasi dan konsumsi, kepada badan usaha dan individu, untuk jangka panjang, menengah dan pendek. Secara lebih spesifik bank dapat berfungsi sebagai agent of trust (lembaga yang landasannya adalah kepercayaan), Agent of development dan agent of services (lembaga yang memobilisasi dana untuk pembangunan ekonomi).

Penilaian kinerja perusahaan bagi manajemen dapat diartikan sebagai penilaian terhadap prestasi yang dapat dicapai. Dalam hal ini laba dapat digunakan sebagai ukuran dari prestasi yang dicapai dalam suatu perusahaan. Penilaian kinerja perusahaan penting dilakukan, baik oleh manajemen, pemegang saham, pemerintah, maupun pihak lain yang berkepentingan dan terkait dengan distribusi kesejahteraan di antara mereka, tidak terkecuali perbankan. Menurut Robbins dalam Jurnal Ekonomi Manajemen Soekiman (2007:91) secara sederhana mendefinisikan keberhasilan organisasi sebagai suatu tingkatan pencapaian atas tujuan jangka pendek dan jangka panjang, mencerminkan konstituensi strategis, minat pengevaluasi, dan tingkat kehidupan organisasi. Menurut Mathis dalam Jurnal Ekonomi Manajemen Soekiman (2007:91) organisasi itu dapat berhasil apabila tujuan organisasi telah tercapai. Jika tujuan organisasi tercapai maka suatu organisasi perbankan dapat dikatakan memiliki suatu kinerja yang baik. Untuk mencapai tujuan organisasi suatu bank harus mengerti mengenai kondisi lingkungan internal dan eksternalnya karena kekuatan internal dan 
eksternal yang mengendalikan perubahan di dalam suatu perusahaan. Menurut Abdullah (2005:201-204) dalam mengidentifikasi kondisi perusahaan menggunakan empat bentuk yang berbeda yaitu:

1. Memelihara keseimbangan perusahaan.

2. Mencegah krisis perusahaan.

3. Mengatasi pemusatan usaha.

4. Memahami ekspansi perusahaan.

Bank dalam melaksanakan tugas dan kewajibannya wajib berpedoman pada prinsip-prinsip perbankan yang sehat dan memenuhi ketentuan-ketentuan yang berlaku. Bank harus memahami fungsinya sebagai lembaga kepercayaan masyarakat, sehingga bank harus menghindari praktek dan kegiatan yang diperkirakan akan membahayakan kelangsungan hidup bank dan atau merugikan kepentingan masyarakat. Dalam hal pelaksanaan ketentuan yang berlaku telah ditetapkan sanksi berupa kewajiban membayar atau dikaitkan dengan penilaian tingkat kesehatan bank serta sanksi-sanksi lainnya.(Tawaf,1999).

Menurut A. Dale Timple dalam Mangkunegara (2000:15) faktor-faktor kinerja terdiri dari faktor internal dan faktor eksternal. Faktor internal yaitu faktor yang dihubungkan dengan sifat-sifat seseorang. Misalnya, kinerja seseorang baik disebabkan karena mempunyai kemampuan tinggi dan seseorang itu tipe pekerja keras sedangkan seseorang mempunyai kinerja buruk disebabkan orang tersebut mempunyai kemampuan rendah dan orang tersebut tidak memiliki upaya-upaya untuk memperbaiki kemampuannya. Faktor eksternal yaitu faktor-faktor yang mempengaruhi kinerja seseorang yang berasal dari lingkungan. Seperti : perilaku, sikap, dan tindakan-tindakan rekan kerja, bawahan atau pimpinan, fasilitas kerja, dan iklim organisasi. Menurut Abdullah (2005:137-138) Faktor yang berpengaruh pada perubahan kondisi internal perusahaan meliputi :

1. Perubahan kondisi perusahaan: Kondisi perusahaan yang sehat dan kurang sehat dapat dilihat dari sisi efisiensi akan berpengaruh terhadap permintaan atau kebutuhan SDM, berupa peningkatan atau pemotongan anggaran demi pencapaian efisiensi perusahaan.

2. Perubahan kondisi karyawan: Perubahan kondisi karyawan yang relatif mudah dilihat dari segi perilaku, penguasaan teknologi, ragam kebutuhan karyawan, tingkat kehadiran, dan perputaran karyawan yang semuanya itu akan berpengaruh pada produktivitas kerja.

Sedangkan Faktor yang berpengaruh pada kondisi eksternal perusahaan menurut Abdullah (2005:141-142) :

1. Lingkungan kemasyarakatan: meliputi kecenderungan beragam dan tekanantekanan umum yang tidak ada hubungannya dengan perusahaan tetapi dapat memiliki pengaruh secara tidak langsung kepada perusahaan.

2. Lingkungan tugas: meliputi kecenderungan-kecenderungan yang berpengaruh langsung terhadap perusahaan misalnya pasar kerja, pasar pelanggan atau klien, pengguna lain dan persaingan. 
Menurut Sukristono dalam Umar (2001:130-138) Aspek-aspek internal industri perbankan dibagi menjadi enam :

1. Aspek Organisasi: dibagi atas empat macam yaitu struktur atas dasar eceran, struktur atas dasar pelayanan, struktur atas dasar nasabah, struktur atas dasar divisi internasional yang terpusat.

2. Aspek keuangan: pada industri perbankan mengarahkan manajemen pada enam sasaran yaitu manajemen neraca, analisis rasio, penilaian seluruh hasil kegiatan, kesehatan bank, manajemen asset dan liability, manajemen modal.

3. Aspek pemasaran: hendaknya manajemen pemasaran memperhatikan aspek produk, aspek promosi, aspek place, aspek pricing.

4. Aspek produksi dan operasi : produk bank, sistem penyampaian.

5. Aspek sumber daya manusia.

6. Aspek sistem informasi manajemen: sub sistem kepuasan pelanggan, subsistem informasi nasabah, subsistem informasi persaingan.

Menurut Rangkuti (2002:18-19), Analisis SWOT adalah identifikasi berbagai faktor secara sistematis untuk merumuskan strategi perusahaan. Menurut Jurnal Ekonomi dan Manajemen (Moerdjono, 2006:20) Analisis SWOT adalah identifikasi berbagai faktor yang merupakan alat pencocokan yang penting yang membantu manajer dalam mengembangkan empat tipe strategi diantaranya adalah

a. Strategi SO atau strategi kekuatan-peluang menggunakan kekuatan internal perusahaan untuk memanfaatkan peluang eksternal.

b. Strategi WO atau strategi kelemahan-peluang bertujuan untuk memperbaiki kelemahan dengan memanfaatkan peluang eksternal.

c. Strategi ST atau strategi kekuatan-ancaman menggunakan kekuatan perusahaan untuk menghindari atau mengurangi dampak ancaman eksternal.

d. Strategi WT atau strategi kelemahan-ancaman merupakan taktik defensif yang diarahkan untuk mengurangi kelemahan internal dan menghindari ancaman lingkungan.

Dalam analisis diagram SWOT terdapat empat kuadran dengan penjelasan sebagai berikut:

1. Kuadran I adalah situasi yang paling diinginkan atau disukai, dimana organisasi menghadapi beberapa peluang lingkungan dan banyak kekuatan yang mendorong dimanfaatkannya peluang tersebut sehingga disarankan strategi yang berorientasi pada pertumbuhan (growth-oriented strategy) untuk memanfaatkan situasi yang menguntungkan.

2. Kuadran II adalah situasi dimana perusahaan dengan kekuatan-kekuatan tertentu menghadapi lingkungan yang tidak menguntungkan sehingga dalam situasi ini organisasi dapat memanfaatkan peluang-peluang jangka panjang dengan produk atau pasar lainnya.

3. Kuadran III adalah situasi dimana peluang pasar yang impresif tetapi dikendalikan oleh kelemahan-kelemahan intern. Sehingga organisasi perlu memfokuskan pada strategi untuk meniadakan kelemahan intern agar lebih efektif dalam memanfaatkan peluang pasar. 
4. Kuadran IV adalah merupakan strategi yang paling tidak menguntungkan, organisasi menghadapi ancaman lingkungan yang besar sementara posisinya relatif lemah. Situasi ini jelas menuntut strategi yang mengurangi atau membenahi keterlibatan dalam produk atau pasar yang di telaah dengan analisis SWOT.

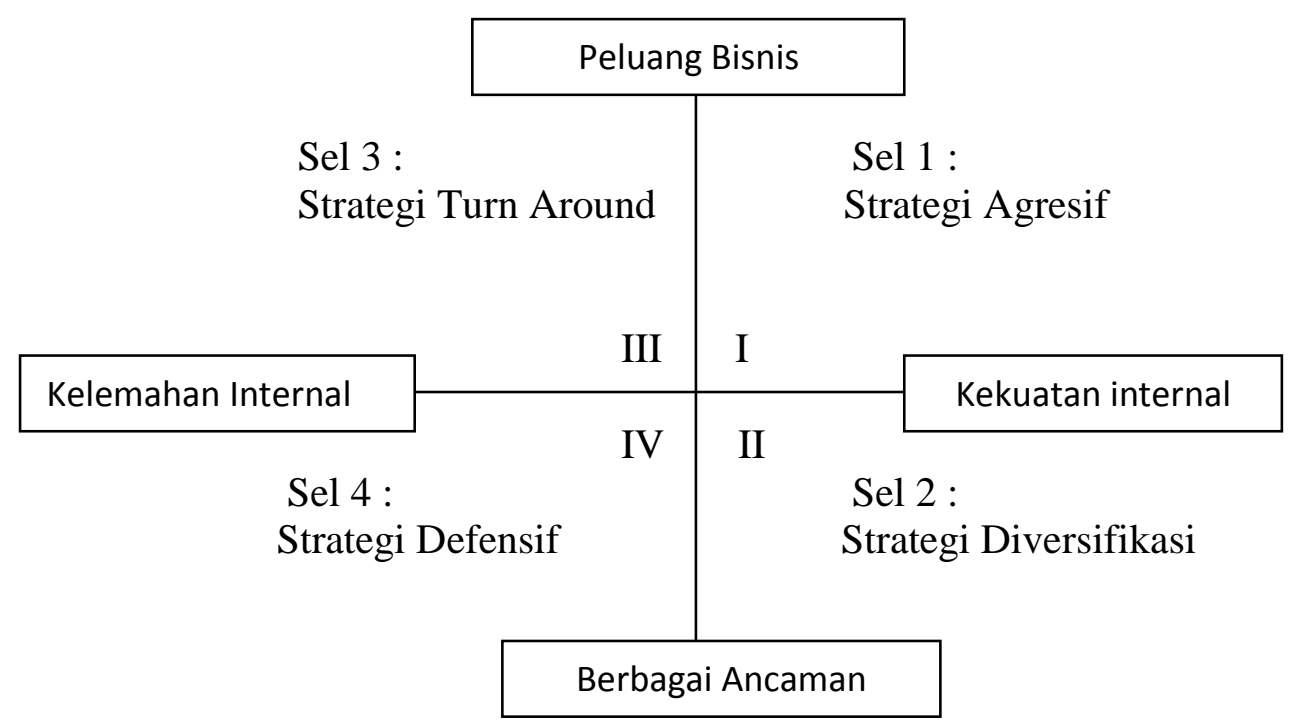

Sumber : Freddy Rangkuti (2002:19)

\section{Gambar 1. Analisis Diagram SWOT}

Matrik SWOT adalah alat yang dipakai untuk menyusun faktor-faktor strategis perusahaan. Matrik ini dapat menggambarkan secara jelas bagaiman peluang dan ancaman eksternal yang dihadapi perusahaan dapat disesuaikan dengan kekuatan dan kelemahan yang dimilikinya. Matrik ini dapat menghasilkan 4 set kemungkinan alternatif strategis 
Tabel 1. Matrik SWOT

\begin{tabular}{|c|c|c|}
\hline EFAS & $\begin{array}{c}\text { STRENGTHS (S) } \\
\text { Tentukan 5-10 faktor-faktor } \\
\text { kekuatan internal }\end{array}$ & $\begin{array}{c}\text { WEAKNESS (W) } \\
\text { Tentukan 5-10 faktor-faktor } \\
\text { kelemahan internal }\end{array}$ \\
$\begin{array}{c}\text { OPPORTUNITIES (O) } \\
\text { Tentukan 5-10 faktor- } \\
\text { faktor peluang eksternal }\end{array}$ & $\begin{array}{c}\text { STRATEGI SO } \\
\text { Ciptakan strategi yang } \\
\text { menggunakan kekuatan untuk } \\
\text { memanfaatkan peluang. }\end{array}$ & $\begin{array}{c}\text { STRATEGI WO } \\
\text { Ciptakan strategi yang } \\
\text { meminimalkan kelemahan } \\
\text { untuk memanfaatkan } \\
\text { peluang. }\end{array}$ \\
\hline $\begin{array}{c}\text { THREATS (T) } \\
\text { Tentukan 5-10 faktor- } \\
\text { faktor ancaman eksternal }\end{array}$ & $\begin{array}{c}\text { STRATEGI ST } \\
\text { Ciptakan strategi yang } \\
\text { mengananasi ancaman. }\end{array}$ & $\begin{array}{c}\text { STRATEGI WT } \\
\text { Ciptakan strategi yang } \\
\text { meminimalkan kelemahan } \\
\text { dan mengatasi ancaman. }\end{array}$ \\
\hline
\end{tabular}

Sumber : Freddy Rangkuti (2002)

Matrik Internal Eksternal (IE) dikembangkan dari model General Electric. Parameter yang digunakan meliputi parameter kekuatan internal perusahaan dan pengaruh eksternal yang dihadapi. Tujuan penggunaan model ini adalah untuk memperoleh strategi bisnis di tingkat Korporat yang lebih detail.

\section{METODE PENELITIAN}

\section{Jenis Penelitian}

Penelitian ini menggunakan pendekatan diskriptif kualitatif dengan jenis penelitian berupa studi kasus yaitu salah satu bentuk metode penelitian, dimana fokus penelitian adalah untuk memahami pertumbuhan sesuatu di masa datang dengan satu latar belakang.

\section{Sampel Penelitian dan Sumber Data}

Pengambilan sampel dilakukan pada karyawan PT. Bank X dengan cara menyebarkan kuesioner kepada responden yang dianggap memiliki kemampuan untuk mengisi kuesioner karena kuesioner sebagai unit analisis utama untuk menghitung skor responden pada tiap-tiap pengamatan serta untuk mengetahui tingkat kepentingan pembobotan dan rating penilaian terhadap lingkungan internal maupun eksternal. Urutan responden adalah sebagai berikut:
1. Direksi
: 4 Orang

2. Kepala Urusan : 1 Orang 
berikut :

Pengumpulan data yang dilakukan dalam penelitian dengan cara sebagai

1. Penyebaran dan Pengisian Kuisioner

Kuesioner digunakan untuk memperoleh data pokok yaitu data untuk mengetahui tingkat kepentingan pembobotan dan peringkat penilaian terhadap lingkungan internal dan eksternal dengan menggunakan pilihan kepentingan.

2. Pengamatan langsung

Penelitian melakukan pengamatan langsung terhadap kegiatan-kegiatan operasional organisasi untuk mendapatkan data yang lebih banyak dan akurat, mendalam serta terinci.

3. Wawancara

Wawancara dilakukan untuk mengetahui tanggapan responden terhadap variabelvariabel penilaian yang telah dirumuskan.

4. Literatur

Literatur yang diperlukan untuk melengkapi data hasil observasi dan wawancara adalah laporan tentang posisi organisasi, data rencana kerja organisasi ke depan serta data kepegawaian.

\section{Teknik Analisis Data}

Dari hasil kuesioner, pengamatan langsung, wawancara maupun literatur yang telah dilakukan analisis dengan menggunakan Analisis SWOT dengan menggunakan analisis IFAS (Internal Factor Anayisis Summary) dan EFAS (Eksternal Factor Analisis Summary). IFAS dan EFAS adalah uraian variabel dalam matrik SWOT. Untuk Variabel IFAS dan EFAS dalam penelitian ini yang dapat ditetapkan untuk proses pengukuran kinerja adalah:

\section{Tabel 2. Variabel IFAS}

\begin{tabular}{cl}
\hline NO & \multicolumn{1}{c}{ Faktor-faktor } \\
\hline 1 & Kualitas Sumber Daya Manusia \\
2 & Pelatihan Sumber Daya Manusia \\
3 & Permodalan \\
4 & Hutang PT.Bank X \\
5 & Likuiditas PT.Bank X \\
6 & Disiplin pegawai \\
7 & Hubungan Personal antar pegawai \\
8 & Manajemen \\
9 & Produk PT.Bank X \\
10 & Nama dari Perusahaan atau Branded \\
11 & Loyalitas pelanggan PT.Bank X \\
12 & Kemudahan pemberian pinjaman \\
\hline
\end{tabular}




\begin{tabular}{cll}
\hline NO & & Faktor-faktor \\
\hline 13 & Kualitas Asset PT.Bank X & \\
14 & Piutang PT.Bank X \\
15 & Sarana dan prasarana PT.Bank X \\
\hline
\end{tabular}

Tabel 3. Variabel EFAS

\begin{tabular}{cl}
\hline NO & \multicolumn{1}{c}{ Faktor-faktor } \\
\hline 1 & Kebijakan pemerintah berkaitan dengan perbankan \\
2 & Perekonomian Nasional \\
3 & Pendapatan masyarakat \\
4 & Budaya masyarakat dalam perbankan \\
5 & Aktivitas masyarakat terhadap perbankan \\
6 & Nilai tukar Rupiah \\
7 & Tingkat suku bunga pinjaman PT.Bank X \\
8 & Tingkat suku bunga Deposito atau Tabungan PT. Bank X \\
9 & Sosial, Politik \\
10 & Produk kompetitor \\
11 & Sarana prasarana kompetitor \\
12 & Partnership atau rekanan bank \\
13 & Produk subtitusi \\
14 & Kebijakan Bank Indonesia \\
15 & Perkembangan usaha masyarakat \\
16 & Perekonomian Internasional \\
\hline
\end{tabular}

Variabel-variabel Internal dan eksternal diatas kemudian dikelompokkan mana yang termasuk variabel Kekuatan, variabel Kelemahan, variabel Peluang dan variabel Ancaman.

\section{Tabel 4. Variabel Kekuatan}

\begin{tabular}{cll}
\hline No. & & Faktor-faktor \\
\hline 1 & Disiplin Pegawai & \\
2 & Hubungan Personal antar pegawai & \\
3 & Manajemen & \\
4 & Produk PT.Bank X & \\
5 & Loyalitas Pelanggan & \\
6 & Kemudahan pemberian pinjaman & \\
7 & Kualitas Asset PT.Bank X & \\
8 & Piutang PT.Bank X & \\
\hline
\end{tabular}


Tabel 5. Variabel Kelemahan

\begin{tabular}{cl}
\hline No. & \multicolumn{1}{c}{ Faktor-faktor } \\
\hline 1 & Kualitas Sumber daya Manusia \\
2 & Pelatihan Sumber Daya Manusia \\
3 & Permodalan \\
4 & Hutang PT.Bank X \\
5 & Likuiditas PT.Bank X \\
6 & Nama dari Perusahaan atau Branded \\
7 & Sarana dan prasarana PT. Bank X \\
\hline
\end{tabular}

Tabel 6. Variabel Peluang

\begin{tabular}{cl}
\hline No. & \multicolumn{1}{c}{ Faktor-faktor } \\
\hline 1 & Budaya Masyarakat dalam perbankan \\
2 & Aktivitas masyarakat terhadap perbankan \\
3 & Patnership atau rekanan bank \\
4 & Kebijakan bank Indonesia \\
5 & Tingkat suku bunga pinjaman PT.Bank X \\
6 & Tingkat suku bunga deposito atau tabungan PT.Bank X \\
7 & Perkembangan usaha masyarakat \\
\hline
\end{tabular}

Tabel 7. Variabel Ancaman

\begin{tabular}{cl}
\hline No. & \multicolumn{1}{c}{ Faktor-faktor } \\
\hline 1 & Kebijakan pemerintah berkaitan dengan perbankan \\
2 & Perekonomian Nasional \\
3 & Pendapatan Masyarakat \\
4 & Nilai tukar rupiah \\
5 & Sosial, politik \\
6 & Produk Kompetitor \\
7 & Sarana prasarana kompetitor \\
8 & Produk subtitusi \\
9 & Perekonomian Internasional \\
\hline
\end{tabular}

Variabel-variabel tersebut diatas diukur dengan menggunakan skala 1 (terendah) sampai dengan 5 (tertinggi). Penentuan skala 1 sampai dengan 5 menggunakan pertimbangan untuk menghindari nilai tengah yang akan menimbulkan penafsiran ganda atas jawaban yang diberikan.

Evaluasi atas faktor-faktor internal dan faktor-faktor eksternal dilakukan dengan melakukan penilaian terhadap faktor-faktor yang menjadi kekuatan, kelemahan, peluang dan ancaman organisasi. Penilaian ini digunakan untuk 
mengetahui pembobotan dari setiap faktor-faktor yang menjadi kekuatan, kelemahan, peluang dan ancaman. Dari faktor-faktor tersebut dinilai berdasarkan skala pengukuran yang sudah ditentukan. Alat pengukurannya dengan menggunakan lima interval untuk faktor kekuatan, kelemahan, peluang dan ancaman yaitu:

Skala pengukurannya :

1 Tidak penting

2 Kurang penting

3 Cukup penting

4 Penting

$5 \quad$ Sangat penting

\section{Pengolahan :}

Nilai Bobot $=$ Jumlah Total Nilai Per Variabel

\section{Jumlah Total Nilai Kepentingan}

Setelah dilakukan pembobotan maka tahapan berikutnya adalah pengukuran kinerja PT. Bank X dibandingkan dengan salah satu bank yang ditunjuk sebagai tolok ukur. Hal ini dilakukan untuk mengetahui rating atau rata-rata dari tiap variabel. Alat pengukurannya dengan menggunakan empat interval untuk faktor kekuatan, kelemahan, peluang dan ancaman yaitu:

Skala pengukuran untuk faktor kekuatan dan peluang (dalam bentuk positif ):

$1 \quad$ Agak baik

$2 \quad$ Cukup baik

3 Baik

$4 \quad$ Sangat baik

Skala pengukuran untuk faktor kelemahan dan ancaman (dalam bentuk negatif ) :

$-1 \quad$ Agak buruk

-2 Cukup buruk

-3 Buruk

-4 Sangat buruk

\section{Pengolahan :}

Rata - rata $=$ Jumlah Total Nilai Per Variabel

Jumlah Total Nilai Responden

Keterangan:

Hasil dari faktor kekuatan dan peluang adalah positif sedangkan faktor kelemahan dan ancaman adalah negatif, setelah penetapan rata-rata maka tahap berikutnya adalah penentuan skoring. Skoring di dapat dari nilai pembobotan dikalikan rata-rata tiap faktor baik kekuatan, kelemahan, peluang maupun ancaman. 
Pengolahan :

Skoring : nilai bobot $\mathrm{x}$ nilai rata-rata

HASIL DAN PEMBAHASAN

Pengelolaan Hasil Kuesioner

Dari hasil penyebaran kuisioner di PT. Bank X maka dari 5 responden menjawab dengan benar sesuai dengan gambaran yang diinginkan peneliti sehingga datanya layak untuk dianalisis lebih lanjut. Data-data tersebut diolah dan dianalisis agar dapat diketahui total skornya.

Cara pengolahan data kuesioner adalah :

a. Pengolahan kolom bobot, diperoleh dari pembagian jumlah bobot dikolom responden tiap variabel dengan total jumlah keseluruhan dari variabel dan hasil akhir kolom harus bernilai: 1,00.

b. Pengolahan kolom rating, adalah hasil bagi dari jumlah tiap-tiap variabel dengan responden yang mengerjakan.

c. Pengolahan kolom skor, adalah dengan mengalikan nilai bobot dengan rating tiap variabel pada kuesioner.

d. Total skor diperoleh dengan cara menjumlahkan hasil perkalian skor.

Setelah mengetahui total skornya, maka metode-metode yang ada dalam analisis SWOT dan matrik-matrik internal, eksternal dapat dikerjakan. Hasil pengolahan data kuesioner untuk faktor internal (kekuatan) dan faktor internal (kelemahan) serta faktor eksternal (peluang) dan faktor eksternal (ancaman) bisa dilihat pada lampiran dengan masing-masing nilai skor sebagai berikut :
a. Total skor kekuatan $=2,84$
b. Total skor kelemahan $=-3,28$
c. Total skor peluang $=2,87$
d. Total skor ancaman $=-3,12$

\section{Hasil Analisis}

Untuk mengetahui kuadran dan strategi yang tepat pada PT. Bank X adalah menggunakan diagram SWOT. Dari pengolahan data nilai total skor dapat dihitung koordinat skor nilai internal dan skor nilai eksternal adalah sebagai berikut:

Tabel 4. Perolehan Skor Internal-Eksternal

\begin{tabular}{ccc}
\hline Skor Faktor Internal & Kekuatan + Kelemahan & $2,84+(-3,28)=\mathbf{- 0 , 4 4}$ \\
Skor Faktor Eksternal & Peluang + Ancaman & $2,87+(-3,12)=\mathbf{- 0 , 2 6}$ \\
\hline Sumber: Hasil Pengelolahan Data &
\end{tabular}


Dari perolehan skor internal-eksternal diketahui bahwa posisi dari kuadran PT. Bank X adalah terletak pada koordinat $(-0,44 ;-0,26)$ berada pada posisi kuadran IV atau berada pada strategi Defensif (W-T). Arah strategi Defensif (W-T) ini merupakan situasi yang sangat tidak menguntungkan bagi PT. Bank X karena dengan arah strategi Defensif menunjukkan bahwa PT. Bank X mempunyai ancaman ancaman lingkungan yang besar sementara posisinya relatif lemah sehingga harus berusaha keras agar dapat meminimalkan kelemahan dan menghindari ancaman yang terjadi.

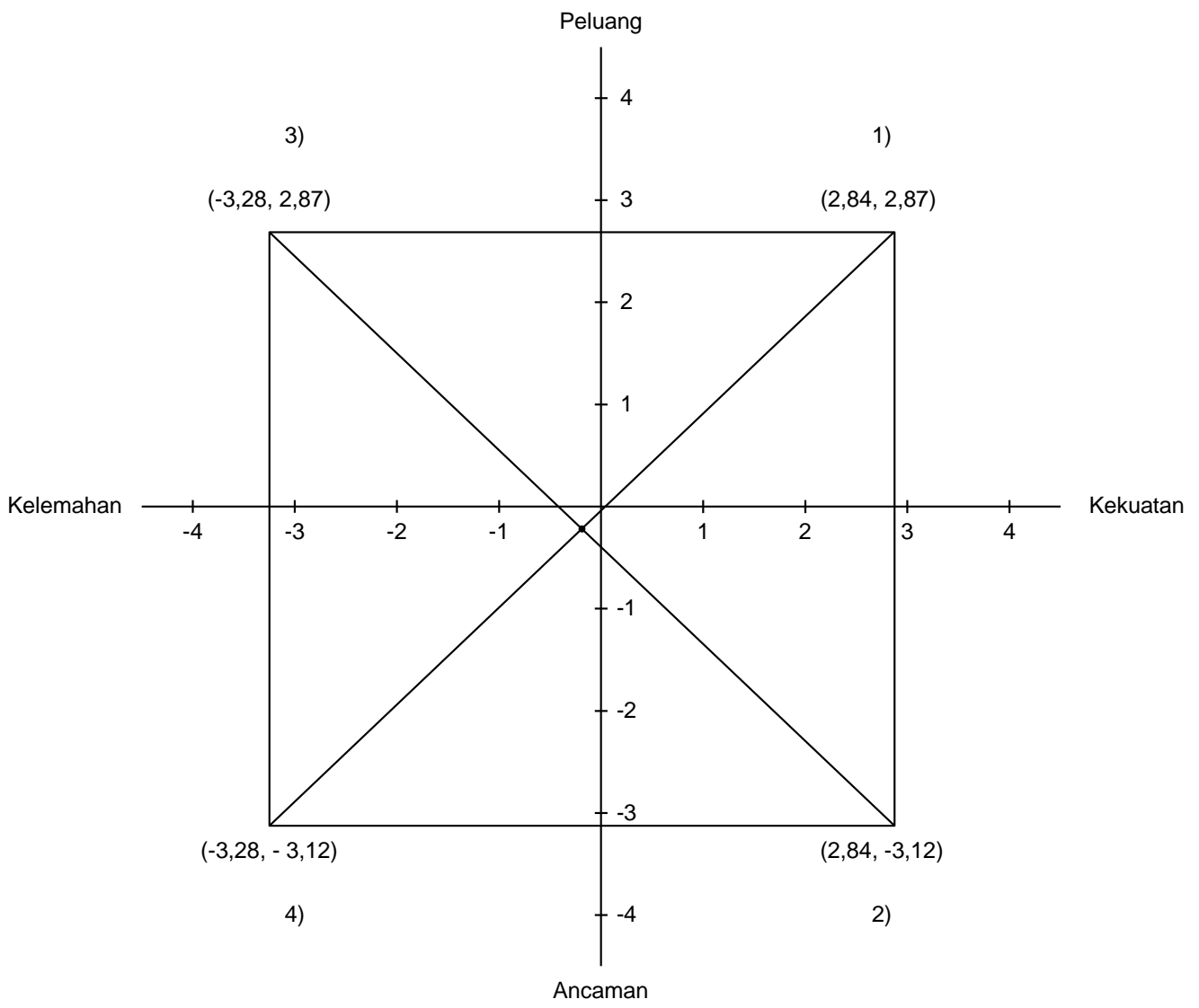

Sumber : Hasil Pengolahan Data

Gambar 2. Diagram SWOT 


\section{Penetapan Strategi}

Untuk memperoleh formulasi strategi yang tepat perlu melakukan analisis SWOT dengan menggunakan berbagai model analisis yaitu sebagai berikut :

\section{Matrik SWOT PT. Bank X}

\begin{tabular}{|c|c|c|}
\hline EFAS & $\begin{array}{l}\quad \text { KEKUATAN } \\
\\
\text { 5. Disiplin pegawai } \\
\text { 6. Hubungan personal antar } \\
\text { pegawai } \\
\text { 3. Manajemen PT. Bank X } \\
\text { 4. Produk PT. Bank X } \\
\text { 5. Loyalitas pelanggan } \\
\text { 6. Kemudahan pemberian } \\
\text { pinjaman } \\
\text { 7. Kualitas Asset PT. Bank X } \\
\text { 8. Piutang PT. Bank X }\end{array}$ & $\begin{array}{l}\text { KELEMAHAN } \\
\text { 1. Kualitas sumber daya manusia } \\
\text { 2. Pelatihan sumber daya manusia } \\
\text { 3. Permodalan } \\
\text { 4. Hutang PT. Bank X } \\
\text { 5. Likuiditas PT. Bank X } \\
\text { 6. Nama dari perusahaan atau } \\
\text { branded } \\
\text { 7. Sarana, prasarana PT. Bank X }\end{array}$ \\
\hline $\begin{array}{l}\text { PELUANG } \\
\text { 1. Budaya masyarakat dalam } \\
\text { perbankan } \\
\text { 2. Aktivitas masyarakat } \\
\text { terhadap perbankan } \\
\text { 3. Patnership atau rekanan bank } \\
\text { 4. Kebijakan bank Indonesia } \\
\text { 5. Tingkat suku bunga pinjaman } \\
\text { PT. Bank X } \\
\text { 6. Tingkat suku bunga deposito } \\
\text { atau tabungan PT. Bank X } \\
\text { 7. Perkembangan usaha } \\
\text { masyarakat }\end{array}$ & $\begin{array}{l}\text { STRATEGI SO } \\
\text { 1. Meningkatkan kualitas } \\
\text { sumber daya manusia } \\
\text { 2. Memelihara kualitas produk dan } \\
\text { mutu pelayanan } \\
\text { 3. Perluasan jaringan pemasaran } \\
\text { produk } \\
\text { 4. Kerjasama dengan pihak asing }\end{array}$ & $\begin{array}{l}\text { STRATEGI WO } \\
\text { 1. Mengusahakan pengembangan } \\
\text { dan pelatihan sumber daya } \\
\text { manusia } \\
\text { 2. Meningkatkan modal } \\
\text { 3. Meningkatkan efisiensi biaya } \\
\text { 4. Menambah sarana, prasarana } \\
\text { sebagai penunjang kegiatan } \\
\text { perbankan } \\
\text { 5. Mensosialisasi mengenai bank } \\
\text { kepada masyarakat }\end{array}$ \\
\hline $\begin{array}{l}\qquad \text { ANCAMAN } \\
\text { 1. Kebijakan pemerintah } \\
\text { berkaitan dengan perbankan } \\
\text { 2. Perekonomian Nasional } \\
\text { 3. Pendapatan masyarakat } \\
\text { 4. Nilai tukar rupiah } \\
\text { 5. Sosial, politik } \\
\text { 6. Produk kompetitor } \\
\text { 7. Sarana, prasarana kompetitor } \\
\text { 8. Produk subtitusi } \\
\text { 9. Perekonomian internasional }\end{array}$ & $\begin{array}{l}\text { STRATEGI ST } \\
\text { 1. Meningkatkan kualitas kinerja } \\
\text { perusahaan yang lebih baik } \\
\text { 2. Meningkatkan kualitas mutu } \\
\text { barang dan pelayanan }\end{array}$ & $\begin{array}{l}\text { STRATEGI WT } \\
\text { 1. Mengusahakan pengembangan } \\
\text { Dan pelatihan sumber daya } \\
\text { manusia } \\
\text { 2. Lebih memperhatikan kualitas } \\
\text { produk dan mutu pelayanan } \\
\text { 3. Menambah sarana prasarana } \\
\text { Sebagai penujang kegiatan bank } \\
\text { 4. Melakukan merger dengan } \\
\text { beberapa bank - bank besar lain }\end{array}$ \\
\hline
\end{tabular}




\section{HASIL DAN PEMBAHASAN}

Pada PT. Bank X terdapat beberapa faktor internal dan faktor eksternal yang berpengaruh terhadap posisi dan kondisi perusahaan namun dari faktor internal (Kekuatan dan Kelemahan) dan faktor eksternal (Peluang dan Ancaman) ada 3 faktor yang sangat berpengaruh karena memiliki skor yang tinggi. Faktor-faktor dominan tersebut adalah sebagai berikut :

Faktor internal (kekuatan) adalah sebagai berikut:

1. Disiplin pegawai : skor 0,46

2. Manajemen PT. Bank X : skor 0,43

3. Kemudahan pemberian pinjaman : skor 0,37

Dilihat dari hasil skor yang berada pada posisi teratas adalah Disiplin pegawai, dimana pada PT. Bank X ini kedisiplinan merupakan budaya yang sudah ada sejak zaman dahulu. Dilihat dari kartu absensi jarang sekali terjadi keterlambatan masuk dan rata-rata tingkat kehadiran per-orangnya $99 \%$ per - bulan sehingga divisi personalia jarang sekali mengeluarkan surat peringatan untuk para karyawan, sedangkan pada Skor tertinggi kedua adalah Manajemen PT. Bank X dimana pada PT. Bank X ini posisi manajemen sudah mengikuti standar dari Bank Indonesia yaitu terdiri dari Komisaris, Presiden Direktur, Direktur Operasional, Direktur Kepatuhan dan Direktur Kredit selain itu job description para manajemen telah sesuai dengan SOP yang telah ditetapkan. Skor tertinggi ketiga adalah kemudahan pemberian pinjaman. PT. Bank X ini akan memberikan jaminan kemudahan kredit jika usaha calon debitur yang akan dicover oleh PT. Bank X ini jelas dan dilengkapi dengan surat - surat yang tepat seperti NPWP, SIUP, TDP dan lain sebagainya. Selain usaha dari calon debitur akan dilihat juga mengenai jaminan yang akan dijaminkan selama kredit berlangsung. Jaminan dapat menyerupai tanah, rumah, mobil dan sebagainya. Jaminan harus disurvei terlebih dahulu oleh pihak bank yang ditunjuk oleh manajemen untuk mengetahui kejelasannya misalnya Jaminan tersebut harus mempunyai nilai yang cukup atau seimbang dengan kredit yang diberikan, Surat surat kepemilikan dari jaminan harus ada dan jelas, jaminan harus diasuransikan untuk menghindari terjadinya musibah sehingga jika terjadi musibah yang tidak diinginkan ada pihak yang menanggungnya. Jaminan yang berupa tanah atau rumah harus disurvei mengenai letak dan posisi bangunan karena akan mempengaruhi dalam proses jual beli jaminan tersebut.

Faktor internal ( kelemahan ) adalah sebagai berikut:

1. Sarana, prasarana PT. Bank X : skor - 0,55

2. Kualitas sumber daya manusia : skor - 0,56

3. Permodalan : skor - 0,66

Dilihat dari hasil skor yang tertinggi adalah sarana dan prasarana dari PT. Bank X, salah satu yang menjadi kelemahan adalah tidak adanya fasilitas ATM sehingga jika nasabah akan mengambil uangnya harus menggunakan slip pengambilan tunai pada bank tersebut. Faktor yang berada pada posisi kedua adalah kualitas SDM. Pada PT. Bank X ini masih terdapat karyawan yang lulusan SMA, 
selain itu karyawan yang masuk terkadang belum memenuhi persyaratan dari yang ditentukan oleh Bank Indonesia misalnya Indeks prestasi kumulatif kelulusan belum memenuhi syarat, jurusan perkuliahan tidak sesuai dengan job description yang diberikan oleh bank tersebut dan lain sebagainya. Pada PT. Bank X belum pelatihan yang diberikan kepada karyawan masih kurang. Faktor tertinggi ketiga yaitu faktor permodalan. Faktor permodalan sangat penting bagi perbankan dimana pada PT. Bank X ini permodalan masih belum memenuhi standar yang ditetapkan oleh Bank Indonesia sehingga permodalan menjadi salah satu faktor yang menyebabkan kelemahan bagi Bank tersebut. Standar yang ditetapkan Bank Indonesia adalah 100 Milyar sedangkan PT. Bank X modalnya belum mencapai 100 Milyar.

\section{Faktor eksternal ( peluang ) adalah sebagai berikut:}

1. Kebijakan Bank Indonesia : skor 0,51

2. Budaya masyarakat dalam perbankan : skor 0,48

3. Tingkat suku bunga pinjaman PT. Bank X : skor 0,46

\section{Penjelasan:}

Faktor yang memilki skor tertinggi pada faktor eksternal (peluang) adalah kebijakan Bank Indonesia. Dengan adanya kebijakan dari Bank Indonesia maka akan menjadikan pedoman bagi setiap industri perbankan dan diharapkan dapat membantu suatu Bank dalam menjalankan usahanya sehingga menjadi bank yang sehat dan berkembang. Skor tertinggi kedua ditempati oleh budaya masyarakat dalam perbankan. Budaya masyarakat dalam perbankan menjadi faktor yang menyebabkan peluang bagi Bank karena di era globalisasi ini semua masyarakat lebih percaya kepada suatu bank untuk menyimpan uangnya. Masyarakat memilih bank karena faktor keamanan selain itu uang akan sedikit bertambah karena adanya bunga yang diberikan setiap bulan. Tidak hanya menyimpan uang masyarakat juga percaya kepada suatu bank jika akan mencari tambahan modal untuk perkembangan usahanya. Skor tertinggi ketiga ditempati oleh tingkat suku bunga pinjaman. Pada PT. Bank X ini suku bunga pinjaman lebih rendah dibandingkan dengan bank-bank umum lainnya dimana suku bunga pinjaman adalah $14 \%$. Dijadikan sebagai peluang karena dengan adanya suku bunga pinjaman rendah maka akan menarik minat masyarakat untuk menjadi calon debitur.

\section{faktor eksternal ancaman adalah sebagai berikut :}

1. Produk Kompetitor : skor - 0,42

2. Perekonomian Internasional : skor - 0,44

3. Sarana prasarana kompetitor : skor $-0,51$

Skor tertinggi dari faktor eksternal (ancaman) adalah Produk yang dimiliki kompetitor atau pada bank-bank umum lainnya memiliki jenis produk yang lebih banyak contohnya: produk tabungan bisa melebihi 5 macam misalnya tabungan biasa, tabungan berhadiah, tabungan pendidikan anak, tabungan rencana keluarga, tabungan dengan dua manfaat yaitu menabung plus mendapatkan perlindungan jiwa atau asuransi. Pada PT. Bank X ini produk yang dimiliki hanya ada 3 jenis yaitu : Giro, 
tabungan dan deposito, untuk tabungan hanya ada 2 macam yaitu tabungan biasa dan tabungan berhadiah. Skor tertinggi kedua ditempati oleh Perekonomian Internasional. Adanya krisis Global sangat mengganggu industri perbankan dalam hal kurs, suku bunga dan ekspansi kreditnya. Kurs Dolar terhadap rupiah akan naik turun, suku bunga juga akan naik turun. Ekspansi kredit akan sangat berpengaruh karena suku bunga kredit tinggi maka masyarakat akan berpikir kembali jika akan menggunakan fasilitas kredit pada bank. Skor tertinggi ketiga ditempati oleh sarana prasarana kompetitor. Sarana dan prasarana yang dimiliki oleh kompetitor dimana disini adalah bank - bank umum lainnya telah memadai contohnya : terdapat fasilitas ATM yang dapat menunjang nasabah dalam pengambilan uang tunai, SMS Banking yang dapat digunakan sebagai sistem pembayaran, mentransfer uang dan sebagainya.

Pada PT. Bank X penetapan strategi diperoleh dari matrik SWOT dimana pada:

1. Strategi SO: dibuat berdasarkan jalan pikiran perusahaan, yaitu dengan memanfaatkan seluruh kekuatan untuk merebut dan memanfaatkan peluang sebesar - besarnya. Diantaranya adalah : meningkatkan kualitas sumber daya manusia, memelihara kualitas produk dan mutu pelayanan, perluasan jaringan pemasaran produk, kerjasama dengan pihak asing.

2. Strategi ST: strategi ini menggunakan kekuatan yang dimiliki perusahaan untuk mengatasi ancaman, yaitu dengan meningkatkan kualitas kinerja perusahaan yang lebih baik, meningkatkan kualitas mutu barang dan pelayanan.

3. Strategi WO: Strategi ini diterapkan berdasarkan pemanfaatan peluang yang ada dengan cara meminimalkan kelemahan yang ada, yaitu dengan mengusahakan pengembangan dan pelatihan sumber daya manusia, meningkatkan modal, meningkatkan efisiensi biaya, menambah sarana prasarana sebagai penunjang kegiatan perbankan, mensosialisasikan mengenai bank kepada masyarakat.

4. Strategi WT : strategi ini didasarkan pada kegiatan yang bersifat defensif dan berusaha mengcover dan mengeliminir kelemahan supaya kelemahan yang ada menjadi kekuatan serta mengeliminir ancaman supaya ancaman yang ada menjadi peluang bagi PT. Bank X.

PT. Bank X berada pada posisi strategi WT dimana pada strategi tersebut PT. Bank X harus berusaha mengeliminir kelemahan dan ancaman. Penentuan strategi diharapkan dapat merubah kelemahan yang timbul menjadi suatu kekuatan dan ancaman yang ada menjadi suatu peluang bagi PT. Bank X. Kelemahan yang timbul paling dominan adalah permodalan, sarana prasarana PT. Bank X, dan kualitas sumber daya manusia, sedangkan ancaman yang paling dominan adalah sarana prasarana kompetitor, perekonomian internasional, dan produk kompetitor. Dilihat dari kelemahan maka PT. Bank X tergolong lemah pada sisi finansial, kelengkapan sarana prasarana dan kualitas sumber daya manusianya sedangkan dilihat dari ancaman maka PT. Bank X tergolong terancam oleh adanya sarana prasarana dari bank kompetitor, perekonomian internasional dan produk kompetitor, untuk itu strategi yang tepat dapat dijalankan oleh PT. Bank X dengan cara: 
1. Mengusahakan pengembangan dan pelatihan sumber daya manusia

Strategi mengusahakan pengembangan dan pelatihan sumber daya manusia dapat berupa mengadakan training tiap tahun kepada seluruh karyawan. Materi training bisa mengenai sistem - sistem yang digunakan pada PT. Bank X, mengenai SOP atau prosedur dan mengenai peraturan yang berlaku pada PT. Bank X. Diharapkan seluruh karyawan mengerti sistem yang dipakai pada bank tersebut dan dapat mengerti setiap perubahan prosedur dan peraturan yang berlaku sehingga karyawan memiliki kemampuan dalam mengatasi segala permasalahan yang timbul pada saat bekerja. Dengan adanya kualitas sumber daya manusia yang memadai maka PT. Bank X akan semakin berkembang dan dapat bersaing dengan bank - bank swasta lainnya.

2. Memperhatikan kualitas produk dan mutu pelayanan

Strategi memperhatikan kualitas produk dan mutu pelayanan dapat dilakukan dengan cara mengembangkan produk yang ada, melakukan inovasi produk baru yang dapat memberikan manfaat lebih banyak misalnya dengan menabung mendapatkan fasilitas asuransi kesehatan, serta meningkatkan mutu pelayanan terhadap masyarakat. Peningkatan mutu pelayanan dapat dilakukan dengan berbagai cara misalnya : penambahan teller dan customer service, pemakaian tenaga satpam untuk penjagaan dan membantu nasabah jika mengalami kesulitan dalam proses pengambilan dan pengisian slip, frekuensi pelayanan teller dan customer service lebih dipercepat sehingga mengurangi antrian nasabah.

3. Menambah sarana prasarana untuk menunjang kegiatan bank

Strategi menambah sarana prasarana untuk menunjang kegiatan bank dapat dilakukan dengan cara kerjasama dengan bank-bank lain untuk mendirikan fasilitas ATM bersama yang dapat membantu nasabah pada saat mengambil uang sehingga tidak perlu datang ke bank dan tidak perlu menggunakan slip pengambilan tunai, mengganti mesin-mesin yang sudah usang contohnya komputer, printer, mesin teraan dan sebagainya, memberikan sistem antivirus pada setiap komputer yang dijalankan sehingga dapat memproteksi setiap datadata yang ada, penambahan sistem cctv pada setiap sudut ruangan yang dapat mengurangi tingkat kejahatan baik dari dalam bank maupun dari luar bank.

4. Melakukan merger dengan beberapa bank-bank besar lain

Strategi melakukan merger dengan beberapa bank - bank besar lainnya sangat penting dan harus dijalankan mengingat PT. Bank X memiliki kelemahan dari sisi finansial yaitu permodalan dimana modal PT. Bank X hanya sekitar $\quad 80$ milyar padahal Bank Indonesia menetapkan posisi modal minimal 100 milyar. Strategi merger dapat dilakukan dengan pemilihan bank - bank yang dianggap besar dan mampu menjadi patner kerja PT. Bank X. Pihak manajemen harus memilih secara detail bank - bank yang dapat bergabung dengan PT. Bank X. Dapat dilihat dari segi visi misi dan tujuan bank, budaya organisasi perbankan, SOP dan prosedur yang dijalankan, serta track record yang dicapai bank tersebut dari tahun ke tahun. Diharapkan dengan adanya merger dapat meningkatkan modal PT. Bank X sehingga dapat memenuhi paraturan yang ditetapkan oleh 
Bank Indonesia, selain itu bertambahnya modal dapat menjadi suatu peluang bagi perkembangan PT. Bank X di masa yang akan datang.

\section{KESIMPULAN DAN SARAN}

\section{Kesimpulan}

Kesimpulan yang diperoleh dari penelitian ini adalah sebuah kesimpulan yang komprehensif terhadap perubahan dan perbaikan strategi di PT. Bank X. Analisis ini merupakan analisis mengenai kelemahan yang ada di dalam organisasi serta ancaman yang ada di luar organisasi.

Dari hasil analisis SWOT yang terdiri dari lingkungan internal (kekuatan dan kelemahan) serta lingkungan eksternal (peluang dan ancaman) didapatkan total skor sebagai berikut: Skor Total Kekuatan = 2,84; Skor Total Kelemahan = - 3,28; Skor Total Peluang $=2,87$; Skor Total Ancaman $=-3,12$

Mengacu pada angka skor di atas dan berdasarkan matrik internal eksternal, maka diperoleh pemahaman bahwa posisi organisasi dari PT. Bank X pada matrik SWOT adalah terletak pada koordinat $(-0,44 ;-0,26)$ atau berada pada posisi kuadran IV atau berada pada strategi Defensif (W-T). Arah strategi Defensif (W-T) ini merupakan situasi yang sangat tidak menguntungkan bagi PT. Bank X karena dengan arah strategi Defensif menunjukkan bahwa PT. Bank X mempunyai ancamanancaman lingkungan yang besar sementara posisinya relatif lemah sehingga harus berusaha keras agar dapat meminimalkan kelemahan dan menghindari ancaman yang terjadi.

Strategi-strategi yang dapat digunakan untuk memperkuat posisi perusahaan di masa mendatang adalah sebagai berikut:

1. Mengusahakan pengembangan dan pelatihan sumber daya manusia berupa training tiap tahun kepada karyawan mengenai sistem yang dipakai PT. Bank X, SOP dan peraturan yang berlaku.

2. Memperhatikan kualitas produk dan mutu pelayanan berupa mengembangkan produk yang ada, melakukan inovasi produk, meningkatkan mutu pelayanan terhadap masyarakat.

3. Menambah sarana prasarana untuk menunjang kegiatan bank berupa kerjasama dengan bank-bank lain untuk mendirikan fasilitas ATM bersama, mengganti mesin-mesin yang sudah usang, memberikan sistem antivirus pada setiap komputer, penambahan sistem cctv.

4. Melakukan merger dengan beberapa bank-bank besar lain berupa pemilihan bankbank yang dianggap besar dan mampu menjadi patner kerja PT. Bank X.

\section{Saran}

Dari hasil penelitian pada PT. Bank X, maka saran yang dapat diberikan adalah sebagai berikut :

1. Pengembangan dan pelatihan sumber daya manusia untuk meningkatkan kemampuan dan kualitas harus dijalankan secara terus-menerus oleh PT. Bank X 
dalam kurun waktu yang tidak terbatas dan diharapkan semua karyawan wajib untuk mengikutinya.

2. Inovasi produk perlu segera dilakukan sehingga dapat menarik perhatian masyarakat. Inovasi produk dapat dilakukan dengan pengembangkan produk yang ada dan memunculkan produk baru misalnya mengkaitkan produk tabungan dengan asuransi dimana jika masyarakat menabung sekaligus dapat tambahan manfaat yaitu asuransi jiwa dan kesehatan. PT. Bank X juga harus meningkatkan mutu dalam pelayanan terhadap nasabah dengan cara memberikan pelayanan secepat dan sebaik mungkin.

3. Penambahan sarana dan prasarana harus segera dilakukan agar dapat menunjang seluruh kegiatan bank. Dengan adanya penambahan sarana prasarana akan menarik minat masyarakat untuk menabung pada PT. Bank X selain itu bank menjadi kompleks dan dapat menyaingi bank - bank swasta lainnya.

4. Dalam rangka menuju Merger maka diharapkan manajemen PT. Bank X melakukan seleksi terhadap calon partnernya, sehingga dari proses seleksi diperoleh partner yang sesuai yang mampu mendukung bank baik dari segi finansial maupun segi non finansial.

5. Penentuan variabel pada penelitian ini adalah merupakan identifikasi yang dilakukan peneliti dan diharapkan dapat dijadikan acuan untuk meningkatkan kinerja PT. Bank X di masa mendatang.

6. Karena keterbatasan peneliti dari berbagai sisi seperti keterbatasan waktu, biaya, literatur dan pengetahuan serta lainnya sehingga bila penelitian dilakukan oleh peneliti lain dan atau pada lembaga lain, maka dengan seiring jalannya waktu hasil penelitian akan memunculkan strategi yang tepat untuk peningkatan kinerja. 


\section{DAFTAR PUSTAKA}

Abdullah, Burhanuddin, 2005, Performance Appraisal, PT. Raja Grafindo Persada, Jakarta

Arthesa, Ade, et al, 2006, Bank Dan Lembaga Keuangan Bukan Bank, PT. Indeks

Budisantoso, Triandaru, 2006, Bank Dan Lembaga Keuangan Lainnya, Edisi Kedua, Penerbit Salemba Empat, Jakarta

Dadang, Indira 1998, Buletin Ekonomi Moneter Dan Perbankan. Memprediksi Kondisi Perbankan Melalui Pendekatan Solvency Secara Dinamis

IAI, 1994, Panduan Audit Bank, Aditya Media, Yogyakarta

Mahsun, Mohamad, 2006, Pengukuran Kinerjha Sektor Publik, Edisi Pertama, Penerbit BPFE, Yogayakarta

Mahmudah, 2008, Tesis, Penerapan Analisa SWOT Variabel Motivasi Dan Kepuasan Kerja Sebagai Dasar Penentuan Strategi Peningkatan Kinerja Pegawai Di Dinas Tenaga Kerja Dan Transmigrasi Kabupaten Ponorogo, Surabaya

Mangkunegara, Prabu, Anwar, 2005, Evaluasi Kinerja SDM, PT. Refika Aditama, Bandung

Moerdjono, 2006, Jurnal Ekonomi Dan Manajemen. Penerapan Analisis SWOT Sebagai Dasar Penentuan Strategi Pengembangan Sumber Daya Manusia

Muhammad, Suwarsono, 2008, Matriks Dan Skenario Dalam Strategi, Edisi pertama, Unit Penerbit Dan Percetakan, Yogyakarta

Rangkuti, Fredy, 2002, Analisis SWOT Teknik Membedah Kasus Bisnis, PT. Gramedia Pustaka Utama, Jakarta

Salusu, J, 1996, Pengambilan Keputusan Strategik Untuk Organisasi Publik Dan Organisasi Non Profit, PT. Gramedia Widiasarana Indonesia, Jakarta

Soekiman, Soesanto, 2007, Jurnal Manajemen Dan Kewirausahaan. Pengaruh Persepsi Dukungan Organisasi Eksternal Dan Internal Melalui Komitmen Karyawan Terhadap Keberhasilan Perusahaan perbankan Di Jawa Timur

Tawaf P, Tjukria, 1999, Audit Intern Bank, Buku Satu, Penerbit Salemba Empat, Jakarta

Jakarta

Umar, Husein, 2001, Strategic Management In Action, PT. Gramedia Pustaka Utama, Jakarta

Wahyono, Hadi, 2002, Jurnal Riset Ekonomi Dan Manajemen. Komparasi Kinerja Perusahaan Bank Dan Asuransi Studi Empiris Di Bursa Efek Jakarta

Wijayanto, Andi, 2004, Tesis, Penerapan Analisis SWOT Sebagai Dasar Penentuan Strategi Pengembangan Dinas Kehutanan Kabupaten Madiun, Surabaya 